\title{
PERFORMING INDIVIDUALISM. TWO TENDENCIES DISMANTLING WAR IMAGERY IN CROATIAN AND SERBIAN HISTORICAL NOVELS OF THE 1960S
}

\section{(KRSTO ŠPOLJAR, RANKO MARINKOVIĆ AND MATE RAOS, RADOMIR SMILJANIĆ)}

\author{
Maciej Czerwiński \\ Uniwersytet Jagielloński, Instytut Filologii Słowiańskiej UJ \\ ul. Ingardena 3, 30-060 Kraków \\ maciej.czerwinski@uj.edu.pl
}

\begin{abstract}
The article aims at addressing the question of representations of World War Two in Croatian and Serbian literature that were subversive in the sense that they queried the legend not simply by rejecting communism and affirming nationalism, but by emphasizing the uncertainty and sensibility of the human beings, a typical modern reaction to violence and, in general, modernist topoi. In this article I will focus on modernist novelistic representations of the 1960s in which the uncertainty and instability of collective warrants are foregrounded. As a result a subversive meaning is produced which contradicts not only communism and revolution but more generally war as such, including the universal features of war such as confronting loneliness, love as an expression of an individual rather than a collective sense of existence, and the impossibility of a valid representation of past events.
\end{abstract}

$\underline{\text { Key words: }}$

war literature, fiction, Croatian literature, Serbian literature, Yugoslav memory, modern novel 


\section{INTRODUCTION}

When speaking about World War Two and its representations in the literatures of Yugoslavia, one gets the immediate impression that the topic of the discussion would be the People's Liberation Movement, Josip Broz Tito, the partisans, fascists, Germans and Italians, the Ustashas, Chetniks, black-and-white visions, total heroes and total enemies, great battles and the consummate victory of the revolution. This is hardly surprising as a number of books were written on this topic and movies, even called 'partisan movies', were made. The legend that glorified the partisans was the central founding myth of the new Yugoslav state, and hence was also a key to an understanding of the collective identity propagated by the regime. Apart from literature and film, the legend existed in other institutions and discourses, such as in schools, pioneer organizations (nearly always obligatory), official celebrations, memorial sites, artistic activities, historiography. It should be said that although there was a common core for this idea, every domain and genre had its own specificity, and also its own dynamics of change. For instance, school curricula were more subject to ideology than literature; literature in turn was more subversive than film, and so on.

A declaratively unified vision was produced during World War Two and afterwards as a result of the victory over fascism of the antifascist guerilla, in which the communists prevailed. 'Fascism' was an umbrella term for all kinds of enemies: external (Italians and Germans) and domestic traitors (the Ustashas, the Chetniks), whereas antifascism was associated exclusively with the communist-led partisans. The conceptual framework of this binary paradigm, an automatically imposed self-understood belief, was very simple: communists (the sole antifascists) were positive and the fascists were negative. Seen in this perspective, World War Two was a struggle between the collective forces of good and evil. Moreover, the binary representation of 'us' and 'them' followed the "imagery of irregular and individualized partisan fighters from the narod (people) confronted with an amorphous mass of foreign fascist invaders who turn the people - more or less involuntarily - into dauntless defenders: into partizane (partisans)! This narrative, with the fascist invasion in the role of a natural catastrophe within the partisan master plot, has been constantly rewritten in Yugoslavia since the 1940s" (Jakiša, 2009: 10).

The war was presented not just as a war of the 'Yugoslavs' against the alien invaders but also as a war against former regimes which were deemed 'reactionary' or 'bourgeois'. Thus, the war had two purposes: national (liberation from the invaders and their domestic auxiliaries - the collaborators) and social (class liberation from feudalism and capitalism). Moreover, the 
communists represented themselves as the sole movement that was capable of reconciling all 'Yugoslavs' and unify them within a new state. In order to defeat evil a new man must be born - a man who understood that the past should be rejected and the future affirmed (a so-called 'čovjek novog kova'). Furthermore, this idealized man was presented, in canonic visions of the partisan myth, as a total hero who, in spite of being poorly armed and unprepared, enters the struggle and vanquishes evil. As David vanquished Goliath (similarly, the Yugoslav leader, after 1948, was presented as the David who defeated the Soviet Union, another Goliath). Inequality was a topos of the literature and film devoted to the war, and a unifying force of the Yugoslav communist ideology ${ }^{1}$. The heroic paradigm, conveyed in various media and genres, implied a strong sense of collectivism which was a dominant perspective in the communist vision of the world in general, not only within the partisan legend. ${ }^{2}$

When the Yugoslav state collapsed, this legend was the first to be officially brought into question. And, thus, both in public discourses and in literature, new visions of the war emerged. These visions were also predominantly collectivistic, yet this time not embedded within socialist myths, but with national ones. This is emphasized within the majority of scholarship. Andrew Baruch Wachtel says:

My premise is simple: the collapse of multinational Yugoslavia and the establishment of separate uninational states - or, even worse, states that have strived to become so despite the inconvenient presence of members of other national groups on their territory - were not the result of the breakdown of the political or economic fabric of the Yugoslav state; rather, these

\footnotetext{
${ }^{1}$ In many instances, new visions of the war were overtly critical of the whole of partisan art, both for its simplicity and its divergence from national and/or democratic values. More recently, however, there have been new approaches that, despite the obvious ideological engagement of this art, attempt to reaffirm partisanship as a subject of scholarship. Miranda Jakiša states: 'So the exploitation of the partisan story by Yugoslavia's (cultural) politics was without a doubt useful for the formation of national unity as well as for personal claims of Josip Broz Tito whose partisan leadership achievements 'predestined' him for a lifetime presidency. Yet the 'myth' of the partisan liberation struggle and the heroic figure of the partisan can by no means easily be reduced to a common denominator or a one-sided function exclusively in state service' (Jakiša, 2009: 18), See also Gal Kirn (Bielefeld, 2009).

${ }^{2}$ Yet, it would be too easy to subsume all books about the war into the category of this simplified pattern. Although, the canonic vision was shaping the trajectory for literary narratives, with abandoning socialist realist poetics as early as in the beginning of the 1950s, there were a number of practices that, from a variety of angles, brought the canonic legend into question in the early Yugoslav period. The infallibility of partisans was questioned by Oskar Davičo, Dobrica Ćosić or Jure Franičević-Pločar; the morality of partisans by Branko Ćopić or Slobodan Selenić; the heroic paradigm by Oskar Davičo, Mihailo Lalić, Ivan Supek, Vjekoslav Kaleb and notably Miodrag Bulatović; the image of the solemnity of war was overturned by Joža Horvat; and the most important concept of the symmetry defining the equal responsibility of domestic fascists, collaborators with the occupying forces from all nations was undermined by Dobrica Ćosić, Branko Ćopić. Yet, the core of the legend was not overruled.
} 
breakdowns, which manifestly occurred and have been copiously documented, themselves sprang from the gradual destruction of the concept of a Yugoslav nation (Wachtel, 1998: 4).

Wachtel insists that after the war the Yugoslav nation did not come into being because Yugoslav multinational policy didn't succeed, due to the fact that it was challenged by ethnic (national) loyalties in nearly all aspects of life. ${ }^{3}$ The author underlines: 'As more and more people saw themselves with less and less of a connection to people outside of their own ethnic group, the possibilities for economic and political compromise diminished' (Wachtel, 1998: 10). The nationalistic reason for the collapse of the Yugoslav state is also examined by Jasna DragovićSoso. Dealing with the Serbian intelligentsia's shift towards nationalism, the author demonstrated how its national activities "tacitly and overtly endorsed Milošević and his national policy" (Dragović-Soso, 2002: 2), and how it influenced the rejection of the Yugoslav idea $^{4}$.

This is indeed the case: national ideas were stronger and more influential than the Yugoslav idea, and their capacity to stir people's imagination therefore undermined Yugoslavia. Yet, there is another issue, maybe less obvious, but equally important, that should be addressed: namely the problem how individualism and individual ways of understanding of reality challenged the idea of (communist) collectivism. This problem would, in turn, problematize the question of the perception of the war, creating an impulse to confront collectivistic Yugoslav identity, and to bring about skeptical attitudes to reality. This aspect seems to be less political than nationalistic agendas or liberalization processes, yet it profoundly influenced critical attitudes to the war and reality.

In this paper I will first define conceptual and theoretical frames, enabling to understand the role of collectivism/individualism paradigm in Yugoslavia's culture and politics, and then turn to the analysis of general trends in fiction about the war. In order, however, to fully grasp the

\footnotetext{
${ }^{3}$ Wachtel gives a number of aspects in which differences were manifested: the Party and state federalization or school curricula. One could also add distinct - nationally-based - cultural and scholarly centers giving birth to differently conceptualized historiography and literature.

${ }^{4}$ There have been a significant number of similar scholarly approaches to the problem of emergence of national ideologies as a response either to the communist totalitarian regime or to the demands arising from the nationalistic expectations of one part of the elite. The focus has been on articulations of new historical truths whose aims have been to demystify the partisan legend and affirm new nationally oriented interpretations of the war and the past in general. Many analyses underlined that literature, alongside other discursive practices conveyed publicly, played an important role in the rejection of the Yugoslav myths, in particular in the 1980s, and thus expressed nationalistic claims. See Ivo Banac (1992), Tea Sindbaek(2012), Nick Miller (2007), Dragan Žunić(1999), Angela Richter (2010), David A. Norris (2016), Maciej Czerwiński (2018).
} 
problem of fiction written in the 1960s, I will first give an overview on what proceeded this decade. Subsequently, I will deal with war fiction of 1960s focusing on literary tendencies that gave rise to the expansion of individualistic approaches and discern two principal trends. In what follows I will take a closer look at war novels published in the 1960s because, as I argue, precisely in this period subversive revisions of the partisan legend, referring to individual experience of the war, emerged. I will deal with Gvožđe I lovor (Iron and Laurel, 1963) of Krsto Špoljar, Kiklop (Cyclops, 1965) of Ranko Marinković, Ratnici (The Soldiers, 1963) of Mate Raos, and Mirno doba (A Peaceful Time, 1969) by Radomir Smiljanić. They, however, represent different types of individualism. Whereas Špoljar's and Marinković's main protagonists represent intellectual individialists, the characters of Raos and Smiljanić represent namless soldiers. I will deal with this problem in the following paragraphs.

Although there are a significant number of studies dealing with Yugoslav war literature, prose concentrating on individual experience of the war has remained a comparatively understudied phenomenon. Where it was the subject of scholarship, attention was drawn either to transcultural implications of literary techniques or to the morality of individual partisans in war and their hesitation in revolution. ${ }^{5}$

In order to entirely grasp the problem of the affirmation of this new and subversive imagination, it is necessary to demonstrate how the idea of experience of the war was changing over time and in which moment the shift toward individualism reached the highest point. After analyzing some of the narratives, I will conclude by providing an argument linking the literary production in question with political settings that might have influence on principal ideologemes of Yugoslavia. ${ }^{6}$ For such an approach to be heuristically reliable, I take literary works not as separate discursive universes but rather as elements of what Yuri Lotman calls 'semiosphere' or that which makes a socially dialogic paradigm (Bakhtinian 'double-voiced discourse'). From this perspective, literary works are interpreted as enactments of certain ideological stances that

\footnotetext{
${ }^{5}$ One such moral conflict was foregrounded in the novel by Dobrica Ćosić Far Away is the Sun. Nick Miller, referring to moral conflicts between two main characters, Pavle and Uča, describes their visions in the following way: "The decision that they face is a difficult one: encircled by Germans on Jastrebac, should they continue to fight as a single detachment on the mountain, or should they divide in two, move off the mountain and across the Morava river, and then take up the fight again? The decision has both military and political sides: Who should decide? Which decision will save the detachment?" (Miller, 2007: 51).

${ }^{6}$ Since literature on the Holocaust makes a separate phenomenon, in this article I am not taking it into account. There are number of literary works in Yugoslavia and in the newly-established countries referring to the Shoah. The most prominent authors are: Ivo Andrić, Danilo Kiš, Aleksandar Tišma, David Albahari, Ivan Ivanji, Miljenko Jergović, Daša Drndić.
} 
are either in accordance or critical dialogue with standard socio-cultural norms. A word is always a response and/or an anticipation of other words and discourses. Thus the employment of experimental narrative (sometimes resembling modernist writings) is not just aesthetic response to realism, that is plausible no longer, but is also an ideological choice: literary works are understood in allegorical connections with other discourses, including political ones.

\section{REJECTING COLLECTIVISM AND PERFORMING INDIVIDUALISM}

The idea of questioning of collective sense of identity in literature did not emerge suddenly and unexpectedly. It happened to be an outcome not only of ideological agendas in Yugoslavia, but also of very complex processes of modifications of all aspects of narrative structure in novel, such as narrator's and characters' construction, ways of presenting time and space (simultaneity and non-chronological order of discourse), and emphasis on human complexity (individual experience and 'internal life' rather than 'external' collective experience). This resulted in the rejection of radical mimeticism which transformed the narrative structure in such a way that it brought into question the logical chronological order and problematized unsophisticated depicting of protagonists, that was characteristic for many realist novels and was radicalized by socialist realism. The literary techniques and tendencies utilized in these novels include internal monologue, introspection, polyphony, shifts of diegetic positions, and so on. Such a development resembles to some extent processes of the affirmation of modernist experimental tendencies in the first decades of the 20th century. And indeed, the tendencies of dismantling socialist realism in Yugoslavia were by some literary scholars (like Predrag Palavestra or Krešimir Nemec) called a 'new modernism' or 'the second wave of modernism'. All such modifications must have provoked the readership in Yugoslavia, accustomed to receive a traditional realist plot presenting good partisans and bad fascists, to re-consider her/his stance towards the idealized vision of the war.

The rejection of collective sense of identity can be seen as a challenge of the legend. This modified paradigm referred to uncertainty of human beings: a typical modern response to violence. I will focus on some novelistic representations in which - by dismissing the established ideals of mimetic transparency - the uncertainty and instability of collective warrants are foregrounded. As a result a subversive meaning is produced which contradicts not only communism, but every collectivistic vision of reality. This inquiry focuses on the rupture that opens up space for a profound understanding of the existence of man, not just in war but also in the universe in a broader sense. As a result, the internal world of the protagonists receives 
attention rather than their external circumstances, the psychological aspect of the human being rather than the social, subjectivism rather than objectivism. The perspective on the individual aspect of the protagonists creates universes in which the individual does not want to die for his/her homeland, unlike in dominant storytelling about the war. Instead he/she wants to survive. Such a protagonist defends himself/herself from the schematic thinking which is imposed by the collective, and defends his/her right to act according to his/her conscience. In so doing, he/she liberates himself/herself from the group, and becomes a free individual. However, such a liberation does lead to happiness because the protagonists in question are existentialist types who are confronted by the senselessness of life, whether or not there is a war under way. In addition, in being a part of the war, they become victims, because in any war the collective paradigm defeats individualism.

\section{'LIMITED INDIVIDUALISM' IN THE NOVEL OF 1950S}

The expansion of individualism in war fiction of the 1960s was preceded by a tendency that can be labeled as a self-controlled subversion of the 1950s that brought about a protagonist of, as I would call it, 'limited individual capacities'. Such a tendency applies to the novels of Oskar Davičo Pesma (The Poem, 1952), the Montenegrin trilogy by Mihailo Lalić, or Dvoje između ratnih linija (Two between the Frontlines, 1959) of Ivan Supek and Nekoga moraš voljeti (You need to love somebody, 1957) of Čedo Prica. In their books collectivism is not, therein, rejected but merely weakened, and ultimately they reinforce collectivism and heroism.

In The Poem two approaches to the war - the collective and the individualistic - are confronted (which was still, by the way, subversive at the beginning of 1950s). The first is represented by a young and radical revolutionary, Mića, whereas the other by his older comrade, a recognized poet - Andrija Veković. The former is for total revolution and a radical collective spirit, while the latter is a bon-vivant, a Don-Juan sort of protagonist, who has an illegalized relationship with a woman. Mića, wanting to preserve the purity of the revolution, aspires to penalize such behavior and denounces him to the leadership of the communist party. Veković is, then, imprisoned by the Gestapo and subjected to dreadful suffering but he does not reveal the secrets of the resistance. At the same time, Mića spends a night with Veković's girlfriend and discovers love. In this vision; a syncretism of love and revolution is established. The revolution does not contradict love, love cannot harm the revolution. In these terms, revolution becomes a more flexible concept, not radically focused on collective aspects but also on the individual needs of revolutionaries. A similar development of consciousness is presented in Lalić's trilogy: Zlo 
proljeće (The Evil Spring, 1953), Lelejska gora (The Wailing Mountain, 1957) and Hajka (The Pursuit, 1960). As opposed to the simplified poetics of socialist realism, the heroism and collectivism here are not automatically inherited through the social-cultural heroic habitus but are presented as a goal that a character must achieve on his own. He has to go through the state of suspicion and doubt but in the end the sense of revolutionary activity is, nevertheless, reaffirmed. The second novel in row, Lelejska gora, introduces the theme of the wandering of the main protagonist, partisan Lado Tajović. Through the circumstances of the war, he is separated from his own unit, and thus loses the support of the collective. Alienation leads to moral disintegrity and deviations, even to crimes that are not characteristic for idealized communists (as already mentioned, crimes were in the partisan legend associated exclusively with the 'fascists'). The deliberate choice of solitude opens the possibility of confrontation with his own weaknesses, and hence, again, the return of the collective. But the return is achieved through individual hesitation, and reaches the highest point in The Pursuit. The third part of the trilogy offers the positive closure. Thus, Lalić's books are not an expression of the destruction of a positive vision of the struggle with fascism and the emergence of the communist revolution. True, the revolution is born in existential pain (which is a deviation from socialist realism), but - after wandering and strangulation - it returns to the right path. The revolution again makes sense. And collectivism is re-affirmed: being alone one may make mistakes but when in the group, the partisans, one is safe because the collective regulates values. ${ }^{7}$ This is how strength of collectivism is emphasized. The same applies to the novels written in the 1950s in which love became a driving force for protagonists' engagement in the war, such as in the abovementioned novels by Ivan Supek and Čedo Prica. ${ }^{8}$ In both instances the main protagonist, respectively Mladen and Polip, refuse to enter the struggle and hope to survive without engagement. Finally they mature but their engagement results not in the idea of revolution itself

\footnotetext{
${ }^{7}$ The same applies to the novel by Dobrica Ćosić, The Sun is Far Away (1951). Although many critics have spoken of the subversive potential of Čosić's book, the claim seems dubious. True, the book questions one of the canonic ideas of the partisans, their unanimity, but, in fact, the core of the legend is affirmed, including the cult of heroism, collective values, the righteousness of the struggle, glorification of the revolution, and so on. For a similar interpretation of this novel, see Vervaet (2009).

${ }^{8}$ I would also argue that Miodrag Bulatović's famous novel Heroj na magarcu (Hero on a Donkey, 1967) can be classified within this tendency. This might seem to be paradoxical as Bulatović created one of the most original and subversive novelistic discourses on World War Two. Yet, his subversion concerns policies of representation but not the idea of collectivism. Although a sense of collectivism is deformed in this book, it remains at the background as the sole positive value to which the main protagonist, Gruban Malić, aspires. Even though he is grotesque, and triggers among the occupiers smiles rather than fear, he is the only character who attempts to defend some principal values, including responsibility for his collective. This is the most important driving force for his activity as a partisan.
} 
but in love. Mladen falls in love with Milica, and Polip with Eva. Thus, they are not convinced by the imperatives of the revolution or the need to oppose the invaders but by their feelings.

\section{THE QUEST FOR UNLIMITED INDIVIDUALISM}

Whilst such characters, typical for the 1950s, had a skeptical attitude to the war but, in spite of doubts and hesitation as engaging themselves in illegal activities ${ }^{9}$, the protagonists in the early 1960 take one step further. They hesitate and, unlike their predecessors, they do not engage to defend themselves or the collective they might represent. They simply refuse patriotic appeals. They embody a weak and lonely individual suffering from the feelings of fear and pessimism; the figure so alien to the communist viewpoint. The works in question, because of different emphasis they put, might be subsumed under two diverse modes of performing of individualism. One is performed intellectually by a character capable of critical and sophisticated argumentation, whilst the other is achieved through a story about nameless soldiers thrown into the war.

What follows is an attempt to address the nature of literary practices that rejected axioms provided by the communist ideology in which individuals were always subject to their collectives. I would argue that emphasizing the individual aspects of war experience over collective ones, and pacifism rather than militarism, enabled not only a critical response to the legend of the war but a rejection of communist Yugoslav ideology. One might object to the assumption that pacifism was subverting the land of 'brotherhood and unity' by saying that pacifist tendencies, which entailed an individualization of main characters, were also promoted by the Yugoslav state. Indeed, Yugoslavia from the mid of 1950s, and as a result of the break between Tito and Stalin (1948), was developing the cultural idea of a 'non-allied' country. It was essentially antimilitaristic, creating a brand of 'third-way' identity between East and West. Moreover, it received a literary-cultural support in the writings of Miroslav Krleža, the foremost Croatian and Yugoslav literary figure, very close collaborator of Josip Broz Tito. ${ }^{10}$ However,

\footnotetext{
${ }^{9}$ Such a protagonist is exploited in the abovementioned novels by Mihailo Lalić and Oskar Davičo, but also in works written by Aleksandar Vučo, Vjekoslav Kaleb, Ivan Kušan, Ivan Supek.

${ }^{10}$ As Tanja Zimmermann underlines: "According to Krleža, the "third path" already had been heralded in medieval times on the territory of the later Yugoslavia. Especially the Bosnian sect of the Bogomils had supposedly developed some kind of "socialism" and abandoned the ideology of the Eastern and the Western Church. (...) Anticipation became Krleža's catchword for Yugoslav culture. Previous cultural manifestations in the southern Slavic region such as the missionary work of Cyril and Methodius, conducted in the Slavic language, the sect of the Bogomils and the autochthone Serbian church were in his view proleptic announcements of the coming of the socialist empire, which found its culmination in Tito’s Yugoslavia” Zimmermann, 2012: 12).
} 
this historiosophical pacifism served only as a political slogan in the Cold War geopolitical order. In reality, Yugoslavia overtly promoted radical collectivist patriotism embedded with heroic narrative (entailing the imperative of subjecting individuals to the collective), had one of the biggest armies in Europe, and some of its internal policies - maybe even most of them were repressive and militant ${ }^{11}$.

Nevertheless, the 1960s brought about more profound ruptures in the communist system of Yugoslavia, on both a cultural and political level. Starting from 1966, which marked the fall of one of the most prominent communists and the head of infamous state security, Aleksandar Ranković, the Yugoslav state entered a new phase: a phase of creeping decentralization and federalization that culminated in the 1974 new constitution. The federalization process made it possible for more independent cultural centers to be created in all Yugoslav republics. These events coincided with the process of awakening of national ideas (the 1967 "Declaration on the Name and Status of a Croatian Literary Language") as well as the expulsion of a number of prominent political figures, such as Croatian Franjo Tudjman and Serbian Dobrica Ćosić, from the party for their 'nationalism'. ${ }^{12}$

New tendencies within artistic representations of World War Two emerged in this period, reaching a highpoint between 1968 and 1971 (Dragović-Soso, 2002: 22). They are believed to have undermined some of the core communist ideologemes, and occurred in literature, film and philosophy. According to Angela Richter, this very moment, the year 1968 of students' revolt, is best epitomized by the appearance of three literary works written by Slobodan Selenić (Memoari Pere Bogalja, Memoire of Pera the Cripple, 1968), Borislav Pekić (Hodočašce Arsenija Njegovana, The Pilgrimage of Arsenije Njegovan, 1970) and Bora Ćosić (Uloga moje porodice u svetskoj revoluciji; The Role of My Family in the World Revolution, 1969), to which one should also add Dragoslav Mihailović's Kad su cvetale tikve (When Pumpkins Blossomed, 1968). All of them depict the atmosphere of disappointment engendered by the revolution and Yugoslav reality in general. David Norris describes this new tendency in prose narrative as

11 The repressive apparatus has various faces, ranging from the activity of the secret police guarding nondemocratic government and limiting freedom of speech, to fully controlled judiciary system responsible for imprisonments of many political and intellectuals figures in Yugoslavia. The Yugoslav state was based on oneparty system, and repressive measures were carried out against everything that might bring this framework in question. Repression tackled also literature and arts. Scholars dealing with censorship, like Marko Lopušina to whom I will return at the end of this article, documented over 550 instances of censorship of literary works.

${ }^{12}$ Ćosić's disappointment with the Communist regime, described as typically Serbian response to the federalization process, is provided in detail by Nick Miller (Miller, 2007). 
follows: "the new prose writers set out to depict contemporary Yugoslavia with its problems of poverty, urban deprivation and lack of coherent direction in a rapidly changing world. The new modernizing order is replacing traditional values and introducing a clash of civilizations." (Davis, 2012: 204).

The same applies to films made from the mid-1960s, labeled as 'the New Wave (or 'the Black Wave'). Although some of them were held up in the censorship for some time, the films directed by Dušan Makavejev, Želimir Žilnik, Živojin Pavlović or Aleksandar Petrović, eventually reached the Yugoslav public (Goulding, 2002: 70; Levi, 2007). They influenced critical reconsiderations of the war, in particular with respect to the problem of the tragedy of the individual during the conflict (Three by Petrović, 1965), deviations of the revolution at the end of the war (The Ambush by Pavlović, 1968; The Role of My Family in the World Revolution by Bata Čengić, 1971) and a criticism of the currents in flowing through communism from Marxist standpoints (The Early Works by Žilnik). Although this tendency was often labeled as the engaged political activity, it was rather anarchic or, as Dušan Stojanović puts is, the activity enabled the possibility that "one collective mythology is replaced by infinite individual mythologies" (Stojanović, 1998: 84). This developing topos of the New Wave films, was also verbalized by the Praxis thinkers. ${ }^{13}$ Referring to the early works of Marx, they emphasized that collective freedom can be achieved only insofar as the freedom of individuals is accomplished, thus a reverse direction from that that was carried out in the socialist state. Ljubomir Tadić, a prominent member of the group, expressed it overtly: "freedom is possible only when man is truly the subject, the creator, of his own fate, and not a mere object over which power is exercised" (Tadić, 1975: 406). Yet, there is a difference between Praxis philosophers and filmmakers. Whilst the former, despite all criticism, believe in progress and in man, the latter express pessimism that also applies to the works I am dealing with here. However, most of the books in question, except for one, were published in the first half of 1960s and thus they can be taken as an avant-la-lettre example of the abovementioned philosophical and film activity.

\section{INTELLECTUAL INDIVIDUALISTS (ŠPOLJAR AND MARINKOVIĆ)}

Špoljar's and Marinković's main characters represent protagonists embedded with critical thinking. The former is an intellectual par excellence prone to speculative argumentations, the

\footnotetext{
${ }^{13}$ The most prominent thinker were Gajo Petrović, Mihailo Marković, Rudi Supek, Ljubomir Tadić. Starting from 1971 authorities were repressing the journal, and with years its members lost their jobs at the Belgrade University.
} 
latter is a teenager but capable to overwhelmingly grasp the complexity and ambiguity of the world. What makes both authors' works similar is a focus on body. In the first novel, the main protagonist is a teenager who not only does not want to contribute to the war but questions more generally the need to resist evil although he knows that brutality, hatred and violence prevail during a war. It is impossible to improve the world and nothing can help: neither revolution nor love. The protagonist does not enter battles and feels only sexual instincts with respect to one girl - Olja. There is no hope, there are no heroes, there is no honorable struggle. There is viciousness, a lack of values, all-encompassing death and chaos. The protagonist is working at a cemetery dealing with, that is to say, cleaning (in the strict sense of the word) the streets of Zagreb of bodies - the people killed in the allied bombardment.

Such an escapist figure focused on himself, framed within a pessimist atmosphere, could by no means be a Yugoslav-communist hero. His incompatibility to subordinate to such a collectivistic paradigm becomes even more radicalized when he verbalizes his individualist stance: "I thought that a man should do all he likes, for himself, and not for some Croatia or something else that was in me deep in the dark" (Špoljar, 1968: 186). Whereas the refusal of the fascist Croatia may easily be understood as a critical response to the Croatian Independent State, which was in accordance with the official Yugoslav master narrative, the 'something else' seems to be problematic. Since there is no clear reference of this expression, the reader must himself/herself infer the referent. Out of a range of possible referents, the one that seems to be the most plausible, is the communist-led guerilla. There are two reasons to accept such an argument. Firstly, the guerilla is the sole relevant opposition to the Croatian state the protagonist might think of. Secondly, the narrator, contextualizing main protagonist's hesitation about his possible engagement, points only one alternative that is embodied by his colleagues who identify themselves with the partisans and are ready to act on their side. But the protagonist refuses to do so. And thus, the 'something else' must refer to the partisans. His individual stance is, thus, in essence anti-collectivistic as no collective utopia gives hope. His individualism is catastrophic resulting in suicidal tendencies; the dead bodies surrounding him - with which he has to deal with - represent this lack of the sense of existence.

In Cyclops the body is presented as a spoil usurped by the state. The main protagonist, Melchior Tresić, does not want to fight and tries at any cost to avoid recruitment. Thus, the focus is not on a struggle between 'good' US and 'bad' THEM, as it typically is in the partisans' legend, but on the struggle between an individual and the abstract authority that wants to control this body. "Now he felt a solid heaviness in him as the dreadful presence of his body. Here it is. 
You'll get me thrown into the cauldron, to the cannibal warriors, where History is being stewed. Everyone will get their portion on the plate, for the sake of national pride. As for the neutrals . . . they will get smoke in the eyes for punishment. They have no pride, therefore they shall have no portion of history." (Marinković, 2010: 133).

The concept of great history in this novel, that was in official discourses glorified, is catastrophic: it is a cauldron in which authorities dump human bodies. The body is not independent, as the protagonist dream about, but serves authorities. The aim of such an image is to question the partisan's ideologemes which coded body as a metaphor of necessary sufferings which lead to salvation and freedom. Despite antireligious and atheistic attitude of the communist ideology, it refers to quasi-religious contents (Musabegović 2008). This statement of the narrator, however, contradicts the communist collectivistic vision. As a result, Melchior has to struggle against the authority over the control of his body. Even though body is normally taken as the symbol of 'self', Melchior experiences his body as something alien, ready to be thrown to a man-eater, to a Cyclops. History is not something we can learn from it but it in itself bears responsibility for sufferings. This makes this discourse even more subversive, as communists had a strong sense of historicity - being in history, understanding history and managing history. Here, history is hardly understandable, and moreover it destroys individuals, as presented in the following fragment:

History is: the Great, the Small, the Tall, the Short, the Meek, the Fat, the Fair, the Good, the Wise, the Beloved, the Just, the Brave, the Pious, the Posthumous, the Quarrelsome, the Bald, the Stuttering, the Lame, the Hunchbacked, the Stern, the Fearsome, the Terrible, the RedBearded, the Landless, the Lion-Hearted, the Father of the People, Born in Porphyry (Porphyrogenitos), the Magnificent... Drunks, murderers, poisoners, cutthroats, arsonists, libertines, madmen... History, the Teacher of Life. (...) We don't want History, we want Life, oh Lord! But what's the use of our prayers to You? She has taken good care of You, too! She drove nails through Your hands and legs, nailed You to two crossed planks, elevated You to the level of historical scandal and entered You into her ledger under the adjective Crucified. Oh Lord, is there any protection from that madwoman? And the Lord said to Melchior in a low, shy voice, None (Marinković, 2010: 134). 
The tragedy of any war ${ }^{14}$ lies not only in the death of people (as in Marinković's idiolect, people are separated from their bodies) but also in the fact that wars are not an affair of the common people but the affair of lords. In Marinković's novel the lords are symbolically represented by the nicknames of various rulers. Such a negative attitude towards feudal order, metonymically epitomized by the lords, fitted the communist belief. A lowly man prays, asking God to let him live in peace, that he not be handed over to the History (ironically: a teacher), called a lunatic. But God offers no hope. Chaos has been and will forever be the human destiny. What characterizes human destiny is solitude. This statement of the narrator - as well as allencompassing pessimism - contradicts the communist visions that claimed the absolute control over history, scientific and moral, and optimistic vision of reality.

The whole of humanity loses in war, and so does Melchior. He in undoubtedly the metonymy of humankind, not the nation as was the case with novels glorifying engagement (this was the case with Davičo's Veković and Supek's Mladen). Melchior is, thus, a loser. Yet, if one decides to deal with his fate in the collectivistic paradigm, such as is propagated officially, than he may be thought of as a twofold loser. He has not only lost his life, he has, moreover, lost the chance to become an honorable victim of the just struggle.

Such a strategy, as used by Marinković, has a multidimensional subversive potential. Firstly, his protagonist, who is foregrounded and with whom the reader sympathizes, is not a David struggling against a Goliath. He is not the total hero who sacrifices his life, but rather an intellectual who simply wants to avoid the war. Secondly, the protagonist does not deliberately want to represent his collective, but to survive at any cost. Thirdly, the protagonist is a pacifist and not a communist. Fourthly, the war is senseless and is not taken as a just campaign against evil. Having in mind that Marinković himself was partisan, this novel is even more subversive. How is it possible, one might ask, that a former partisan, who put his life at risk in wartime, provides such a senseless vision of the military conflict? What happened between 1945, when he bravely fought against fascism, and the peaceful year of 1963? No matter what answers to these questions are, the figure of Melchior is not, using the theory of John L. Austin, describing a person but rather performing it. According to speech act theory, performative acts are not

\footnotetext{
${ }^{14}$ This is a clear point of reference, in typical Marinković style, to a pacifist idea elaborated by Miroslav Krleža, as a response to the sufferings of World War One in his famous collection of short stories Hrvatski bog Mars (The Croatian God Mars, 1922). The narrator in Krleža's discourse says: 'The fact that various great empires arose and collapsed on the shores of the European seas, the fact that new countries have been discovered, the fact that life has changed significantly, this has had no importance for the life here' (Krleža, 1973: 12).
} 
truth-evaluatable, they simply give birth to something. There is no use asking whether Melchior is true (or if he is an alter ego of the author). There is a need to ask why he was invented, what reasons and circumstances (settings) there are that made him come into being. One of the answers could be: this character is a reasonable individualistic (and don't hesitate to call it humanistic) response to war and its destructive nature. Intellectual individualism contradicts the vision of war promoted in the state by the partisan legend.

\section{NAMELESS SOLDIER: RAOS AND SMILJANIĆ}

The second tendency puts a different stress on modeling of the literary universe, including the protagonists taken into awareness. There is no focus on a specified protagonist, a character that is the main hero of the book, but on individuals who are a part of a group of people. Moreover, unlike in the novels of Špoljar and Marinković, they are real soldiers but not the unrealized ones. And in contrast with the novels by Špoljar and Marinković, there is no psychological inquiry of the protagonists, no introspections into their speculative and philosophical argumentations but there is a stress their pure existence and social interactions. It means that the individualistic perspective, achieved by virtue of metonymy, is accomplished in a different way. Every human being, no matter if a perpetrator or an affected by him/her, is a victim of war. The reader, at first glance, distinguishes bad and good characters but in the course of the narrative, their roles are getting somewhat blurred. Someone who is a culprit of crime might be soon a victim of it. The mechanism of changing of the roles enables to express the conviction that people in any war might be at the same time perpetrators of crimes and victims of them ${ }^{15}$. Although the books in question are different in some respects (whereas the former is a sequence of images that can be by inference taken as a unified plot, the latter is based on a coherent chain of events culminating with a final; whilst the former is more lyric and meditative referring to the lack of cohesion in the world, the latter is more prosaic stressing the idea of plot progression), they have some important features in common. There is no chronotopic constraints in both novels enabling one to know where and when the action is really set (in contrast, the novels of Marinković and Špoljar were placed in a concrete urban space, namely

\footnotetext{
${ }^{15}$ A similar strategy was utilized by the director Aleksandar Petrović in his famous film Three (Tri, 1965), which was based on short stories about the war written by Antonije Isaković. The movie, constructed as three episodes or variations, is about a man who finds himself in three situations. He might be a by-stander of the committed crime, a victim of the crime and a perpetrator of the crime.
} 
in Zagreb). Moreover, nearly all characters have no names and no descriptions (in contrast, previous protagonist were named and described).

Space in both novels is deformed to such an extent that it doesn't come to terms with readers' expectations. There are, of course, mimetically represented real referents of topography like trees, fields, rivers, mountains, graves, machine-guns, buildings, and people but they seem not to be arranged according to realistic standards. When giving information about settings, the narrator refers only to some elements which seem not to be so important for the narrative. It is not explicitly said where the deictic centre is situated although there are linguistic expressions enabling to imagine a place where the soldiers are and from where they move. And thus something that is come across might be 'here' and 'there', 'in front of them', 'further', 'more northern', and so on. The same applies to the characters. Except for one, to whom I will return, they have no names but predominantly are referred as 'he' (rarely 'she'), or simply by his function - as 'soldier' ('vojnik'), 'typist', 'chief commander' ('glavni vođa'). The ambiguity of reference, that weakens the ability to esablish a clear vision of plot details, is strenghtened by the obstacles with text coherency. Coreferential nominal elements are sometimes fuzzy, and the reader cannot infer who the narrator is speaking about. This is notably the case with the Raos's book where it is hard to bring the narrative units together. It sometimes seems that a protagonist is changing roles in the war, and thus embodying various war situations. He might kill someone or gets shot by someone else. Thus individual protagonists are metonymic, and they represent every human being. So the 'he' could easily be a 'they' - a nebulous mass of people, those who were engaged into the war. Such a technique enables to present solders as anonymous victims of war. The reader infers that everybody might be in their position, no matter what precisely his role in war really is.

The two analyzed novels refer not to World War Two directly but to war as such but it is easily to infer that the experience of World War Two is allegorically represented. At the same time the authors create a universal vision of war which goes far beyond a particular time and space. Unlike in Marinković's or Špoljar's novels, the victims are not just people recruited by the state but a number of people of various ages and from various social strata. This is how a mobilization is depicted by Raos:

They separated women from children: women and children were taken to the slope. The old men were settled under the caves. A place was dedicated to the girls. The men were sent to the middle, so were the boys. O their chest the numbers were put. Uniforms, taken from the stacks, were distributed among the men according to their stature and their duty. The food was 
distributed from the other stacks, and so was the weapon from the other. And then, they were taken to a breathing for the layout (Raos, 1963: 6).

And elsewhere:

This is how the assignment has started. In the first row those to die first were deployed: the boys were deployed. In the second row [were deployed] the men; they were given more bullets and weapons, and also, as reinforcement, they selected boys with more bullets and weapon. More food was distributed among them as well. Hence, in the second row were the men and select boys with more equipment and more food. The older and more tired were deployed in the first row, they were fed, and distributed among them were guns, vehicles, tents, bandages and medicines, tools material, gunpowder and covers. The girls were deployed in a special row; they were given knives. They were told: squeeze our domestic weeds, squeeze the hidden weeds. Cheers! (Raos, 1963: 9).

This image encapsulates a typical war situation - the purposelessness of cruelty and destruction, alienation and existential senselessness. In any war there rules a certain hierarchy: soldiers who will soon become murderers are victims at the moment of mobilization. Someone has determined their role in the war, someone has given them uniforms and ordered them to kill. The force that manages wars is abstract and thus inhumane, and hence has no direct connection with real life. The original text uses active forms with no grammatical subjects (i.e. 'narediše') which, due to the grammatical capacity of Croatian language, do not require a pronoun as they would in English. The use of a pronoun refers to a 'they', yet it is not clear who the 'they' really is. The aim of such a strategy is to underline that there is an implicit agent which is not explicitly expressed. Such an avoidance refers to the semantic role, the agency, that influences patients, but in this instance it is not clear where this force is coming from and who gave it the possibility of being in such a position. There is a process but there is no agency. In the following fragments there is the figure of a chief commander but he has no name. This is how he commands:

Brothers in war, there is an enemy before us, a disgusting stain, and we must, as soon as possible, wipe him off the face of the earth. As supreme commander I order you, all of you and each one of you:

first: whenever and wherever you seize the enemy, kill him!

first: if you seize a wounded fighter or a fugitive who has at least one healthy tooth, kill $\operatorname{him!}$ 
first: be in groups to avoid being killed, but should one of your number separate from his group, kill him!

first: defeat the enemy, and those who are not defeated, kill them!

first: do not touch the women and children because they are not dangerous but just so they won't become dangerous, kill them!

first: set everything ablaze, destroy it all with gunpowder, destroy the houses and towns. Kill everybody who resists you!

first: at the moment of victory do not celebrate, do not touch those who celebrate, kill all who are sad in the moment of victory!

first: kill everybody whom you come across. Those who come across no one should kill themselves! (Raos, 1963: 9-10).

In these fragments the agent is somewhat disambiguated. Yet he is still an unknown chief commander about whom we know absolutely nothing except for his capacity to commence processes and affect patients. By performing this role, he embodies an abstract power. The link between the invisible and abstract agent and visible and the concrete patient establishes a peculiar causal relationship. Although Marinković and Špoljar did not use an identical linguistic strategy, they expressed the same awareness, namely that this authority has power over man, and cruelly exploits it. There is, however, one difference between the two tendencies. In Raos's and Smiljanić's novels victims do not resist the mobilization and do not plan their escape, as Melchior did, but instead they offer no resistance and do what they are ordered to do. Melchior is a typical modern (modernist) hero - the escapist who is intellectually resisting reality, whereas Raos's and Smiljanić's, protagonists represent a nebulous mass subject. In both instances the outcome is the same: they become victims of violence.

War is absurd not only because it represents an inconceivable evil but also because an invisible hand - having no particular image or name - is wielding power and bringing terror. In both instances the image of the world is radically abnormal, which is reinforced by the use of hyperbolic constructions, syntactic parallelism, and imperatives, so that this world seems radically deformed to the reader. In Raos's novel there are some absurd, even surrealistic images. A meeting of two enemy soldiers ( 'he ['on'] and 'him out there' ['onaj tamo']) who want to kill each other end up with postponing the execution which is inevitably carried out, by the both of them at the same time.

The strategy of masking the identity of soldiers was also used by Radomir Smiljanić. In his vision, the war (only a few suggestions hint that this is World War Two) is limited to one 
planned clash between two sides that are presented as enemies. It is not clear, however, who the offender and the defender are and what the battle, which is to take place, is about. The narrator focuses only on one side and this is the side which, in the course of the plot, is presented as one that attacks. Interestingly, it is unclear whether this particular side is just and positive. This uncertainty is notably subversive for the legend of the war created by the partisans, since in the legend it was clear who the heroes and the bad guys are. In this novel, the atmosphere of the approaching clash is defined by the very role of the narrator: he describes who is about to clash with whom and under what circumstances but he gives no detailed information so everything is fuzzy, and the readers' expectations for more precise information are thwarted. With only one exception, the soldiers have no names and no nicknames, only military symbols, and the communication between them is enigmatic, as it is in this fragment.

- Everything will change in a few days, everything... - he said dully.

- Change - has been repeated as a refrain. They marched together, this is what they were doing.

- We are leaving - added the typist later on.

- Where to - was the question heard.

- We're leaving soon...

- Where to? - the question was repeated again in a chorus of all present.

- I knew it is going to be this where to... - he muttered to himself but the others heard his words in the confusion (Smiljanić, 1969: 18).

There is another fundamental rejection of the Yugoslav communist mythology in this book. Whereas the communist ideology seems to believe that being in the group of people makes it possible for individual to find his/her way to happiness and bright future, here the individual is always in danger of losing his/her way. One has to remember that the idea of communist utopia was built on the premise of an idea of progress leading to the promised future. Communism was in this perspective seen as the most developed state, and the ultimate aim of the path. When looking at traditional realist and notably socialist realist narratives from the 1940s and 1950s, like by Josip Barković or Oto Bihalji-Merin, partisans were represented as being metonymies of their collectives, as those who know where the path is and how to get to the bright future. In a modernized manner, this axiom was modified to depict partisans losing sight of their path, but ultimately finding it. One can wander around, like in some novels, but at last one finds his way, either by finding one's partisan unit (Vjekoslav Kaleb) or one's real values (Oskar Davičo) 
or both (Mihailo Lalić, Ivan Supek, Ivan Kušan, Jure Faničević Pločar). Unlike in the abovementioned novels, the discursive strategy employed by Smiljanić produces an allencompassing uncertainty, just like in a forgotten book by Meša Selimović Fog and Moonlight (Magla i mjesečina, 1966). Nobody finds his way. This vision refers not only to figures and circumstances but also to the reliability of the narrator and, moreover, the plausibility of the representation of the war. The war seems so absurd that one can only deform it by hiding some rational elements of this construction (like the figures and circumstances that the reader wants to discover, and expects the narrator to disclose) and foregrounding instincts that drive the world. Impressions over descriptions, fragmentations over general overviews - this is what makes this book experimental.

The vision of the enemies is even more fuzzy. From time to time one can think that the enemy does not exist at all but is imagined, that comes into being as a projection, paranoiac image in the soldiers' minds who crave for an enemy. "The enemy on the other side was no longer visible. (...) Maybe, in fact, there was nobody there? Maybe." (Smiljanić, 1969: 75). The enemy is sometimes described as 'invisible and, one might even say this, non-existent, in a way' or the 'invisible defender'. The colonel, who is supreme commander of the unit and organizes a deployment of the troops, orders new inquests and new strikes. However, the enemy is still not visible although there are a lot of words referring to them. Such a projection or even fabrication of an enemy is a performative act, just as is the act of writing fiction. In one such endeavor the colonel issues orders to persecute the enemy: 'Hence the enemy, once more, did not show their face but this - according to officers who surrounded the colonel - needn't prevent people from charging at them and steping on their heels. One had to charge at them. One had to' (Smiljanić, 1969: 102).

There is at first glance a similar construction of the enemy in Raos's novel: the abstract 'alien army' ('dušmanska vojska') or 'enslaver' ('porobljivač') which is about to be entirely destroyed in an 'upcoming' or 'decisive battle' ('predstojeća' or 'odlučna bitka'). Yet, whilst the enemy in the novel of Smiljanić remains unknown (imagined/projected), in the book of Raos it is represented by individuals who clash with other individuals. Although there are provided the outcomes or the war (the killed, graves, and so on), no real fight of the two armies occurs. The struggle is embodied by physically existing individuals.

The aim of the struggle in both novels is total destruction of the enemy. It is uncertain who is in command or whose orders are to be executed. What is certain is that acting in accordance with the orders was obligatory. There is the same construction of the enemy in both novels - 
they are total and irreconcilable. There is an order in Smiljanić's novel: 'The guilty are all those men and women who cooperate with our enemy' (Smiljanić, 1969: 171). This, in turn, leads the unit to order a group liquidation of the captives. This vision represents an individual war situation but very atypical in comparison to the partisans' legend.

On the surface, the works are representing narratives about an anonymous military unit that is struggling against another unit in an unknown place. In parallel, however, it can be understood as a twofold allegory of both World War Two and of the Yugoslav state governed by a person who has indefinite powers, legalized by undetermined authority, and masses of people who blindly follow its decisions. Through the fact that the decisions seem not to have logical reasons, indeed they look irrational, the reader directs his attention to the idea of agency. If accepting the interpretation of war that this work depicts then the answer would be simple: this is what every war looks like. If, however, one decides to understand it as allegory of Yugoslavian society, then the question becomes more complicated: whose decisions are to be carried out? Such an answer is on the reader's side as the protagonists of the book, the individual soldiers, are presented as characters with no active reasoning. They automatically respond to orders. Moreover, there is an atmosphere of fear instilled, as the commander has all the power, and the soldiers follow his orders and behave according to his will. This chief commander could be decoded as Josip Broz Tito who himself was a chief commander of the Yugoslav guerilla before seizing power after the war. The commander's orders are not rational and understandable, and there is no need to provide causes for this or that decision or action. All of them are verbalized with authority, and are carried out without doubts. The soldiers who are believed not to act according to rules are taken as traitors. This happens to a typist from the Smiljanić's novel who is, incidentally, the only character in the book that has a name, Petar Klošar. Klošar in English means 'tramp' - a person with no permanent residence, thus deliberately marking him out as a symbol subject to repression and devoid of individuality.

The conclusion of the two novels also deserves conclusion as they impose additional meaning to the understanding of the role of individualism. The last image of Raos's book provides also unexpected solution. There are three soldiers (described in abovementioned way as 'one was young, the second also and the one who was digging the hole was also young', Raos, 1963: 62) presented in a dramatic scene as they are digging a grave. The grave is devoted to one of them - the one who will be chosen to be killed as a 'hero who was killed for his homeland' (Raos, 1963: 64). The reader does not know why they want to burry one of them as they belong to the same army. One of the answers might be: they do it because the war is always transformed into 
a legend in order to create a collective justification of it. The protagonists' behaviour represent, thus, ironical and critical response to this demand. This, however, drives the imagination by suggesting that this is not a deviation but rather a surrealistic translation of the horrors of every war. The conclusion of the book of Smiljanić is even more unexpected. Once the reader think that he/she will be eventually informed about the enemy, a torrent emerges as a rupture. We are given no information about where it has come from: the water from a river rises and floods everything. The final images of the novel resemble the images of the floods from the Bible. 'Everything disappeared (,..). And soon afterwards everything became water' (Smiljanić, 1969: 251). After the floods, all subsided and the serenity of the water 'came from an allencompassing peace. The water blended with the fossilized sky, and made a visible and audible totality in their stillness: the stone mirror' (Smiljanić, 1969: 252). The new world, in contrast to the Biblical vision, offers no life apart from peace. This world does not have its Noah. The catastrophe brings peace to the world because there are no men any longer. This is the Apocalypse. Such a vision does not only contradict war imagery, in which there are clearly defined cruel invaders and just defenders, but it also contradicts communist metanarrative with the promise of the bright future. There is nobody who could save the world, even communists.

Such a polyphonic construction of the novels creates a strong sense of uncertainty about human being and its presence in the world. If one does not believe in reality, how can one believe in the possibility of its just arrangement? Moreover, the image of the war, as depicted in Raos's and Smiljanić's novels, is subversive from the viewpoint canonized in the sacred legend of the People's Liberation Movement. Were their soldiers to be identified with the Ustashas or Germans, then one could justify their role in the war: they bear no responsibility for the war since someone mobilized them, gave them weapons and ordered them to shoot. The responsibility lies with the chief commanders but they are abstract, hidden and unknown. If Raos's soldiers, however, are identified with the partisans, then the People's Liberation Movement - officially interpreted as just and justified - is stripped of its sacredness. In very many novels, on the other hand, readers do know who the perpetrators and victims are (this was a standard technique - to name the enemy and to depict him, including giving historical figures). The perpetrators are the occupiers, whereas their victims are civilians and the partisans who'd been organized on the sly. Thus many novels - even though it somewhat individualize victims - fails to avoid black-and-white depiction of perpetrators and their victims, and therefore does not emphasize an individualistic experience of the war. Not surprisingly, they are devoid of subversion. 


\section{CONCLUSION}

In line with the analysis, two tendencies giving rise to individual experiencing of war were envisaged. The first is focused on individuals similar to those constructed by Davičo, Supek and Kušan: characters who are hesitating but having a potential to modify their stance which results in the engagement in the war. Yet, in contrast with the tendency of the 1950s, the protagonists in question - embodied by in Iron and Laurel by Krsto Špoljar and Cyclops by Ranko Marinković - do not change their mind and don't reach maturity in the course of the revolution but simply stay as they are. In contrary to the activists promoted by the partisan legend, they remain nihilists, and do it consciously, even deliberately. They are intellectuals or at least characters with capacity to speculative thinking and so their argumentation remains immune to collectivistic appeals. They neither believe in bright future nor in utopias in general.

The second tendency is focused on protagonists taking part in the war but, in contrary to brave partisans known form earlier standard literary works, they are not enthusiastic about it, but happen to be victims of the military conflict and generally embody tragic fate of human being in war. This applies to The Soldiers of Mate Raos and A Peaceful Time by Radomir Smiljanić. In contrast, however, with the first tendency, the protagonists of this trend are not intellectuals aware of their desperate situation but rather ordinary people who simply suffer from evil. Their unawareness becomes a sign-vehicle, in semiotic sense of the word, referring to such a tragedy but which has to be inferred by the reader. Their incapacity to understand their position (or at least it is not explicitly put forward by the narrator) triggers the reader to penetrate his/her cognitive potential making it possible to realize how horrible any war is.

The trend to focus on individual fate within war narratives, instead on emphasizing collectivistic partisan legends, emerges notably in the beginning of the 1960s, and continues to be a part of literary production in to the 1970s and 1980s but without ever dominating, although in aesthetic terms it is at this point that it reaches the highest achievements. The literature in question chiefly rejects not only the poetics of a simplified socialist realism which was finished in Yugoslavia in the beginning of 1950s, but also traditional realism. It introduces a modern realism or, most often, modernist modes of writing. The focus on individual experience in the war questioned communist warrants, and communism, though built upon the profound negation of traditional values, inherited from pre-communist times a system of values and a strong sense of collectivism and militarism. Individualism was, thus, not only opposing tradition and family (as for instance described by Jenifer Presto in her study on Blok's modernist subversion, see Presto 2004) but, paradoxically, also the communist anti-traditional attitude. In this sense, both 
national and communist ideologies were traditional in understanding sense of collectivism, group solidarity and, hence, militarism. The quest for individuality was against any kind of collective ideology. Thus, individualism entailing pacifism was anti-collective equally towards both nationalism and communism.

And to conclude, one could ask how it was possible that such subversive war visions undermining the official legend emerged, and were even state-financed, in a country such as one-party and non-democratic Yugoslavia. Although there were various ways of exerting pressure on writers and even straightforward censorship in Yugoslavia, it hardly ever concerned formalistic experiments, at least after the beginning of 1950s (when the Agitprop finished its activity). According to Marko Lopušina, in the period 1945-1991 there were 570 books prohibited (most of them were the publications written abroad) (Lopušina, 1993). The censorship - that had in his view four forms: legal, self-managed (by local working people organizations), political (by the party commissions), and police (books published abroad) - was carried out for a variety of reasons: for real or presumed nationalism, antisocialism, hostile propaganda, defamation of the image of the state, its party and members (Josip Broz Tito). Yet, no action was taken against experimental idiolects offering subversive approaches to reality. Thus, writing about the war in modernist, neo-avantgarde or postmodernist poetics was possible, and did not find itself accused of decadency, unless overtly canonical visions were violated. To put it differently: writers could experiment in language and in representation of war events, even violating mimetic transparency, unless this challenged general taboo aspects of the war. ${ }^{16}$ None of the analyzed novels had problems with censorship, and none of them,

\footnotetext{
${ }^{16}$ Among these taboos was a concern with nationalism, in particular the depiction of partisans and fascists (the former, even if making mistakes, generally should represent the positive side, whilst the latter the opposite ), as well as the prohibition of the representing of some events which were kept in secret. Three examples of censorship at work are as follows: one concerns the novel by Serbian writer Vojislav Lubarda, and another is the example of Croatian Dubravko Horvatić. Lubarda provoked a huge scandal with the publication in 1969 of a chapter of his planned novel Proud Stumbling (Gordo posrtanje) in the journal "Život" in Sarajevo. The reason was that he presented many of the distinguished antifascists from his hometown Rogatica - all Muslims - as the Ustasha (he incorporated real people, including his father, into fiction), and that he equated partisans with the Chetnik. He, however, found another publisher, paradoxically in Croatia. Yet, the book could be published as he changed real names into fictional (thus, Lubarda became Lukarda, Rogatica became Čaršija). This very fact demonstrates who federalized Yugoslavia was. What was impossible in one republic, might be possible in the other. Horvatić's story The Lead Valley (Olovna dolina), written in 1974, was published as late as in 1989 due to its associations with the Bleiburg Valley where the communists massacred thousands of fascists and alleged fascists in 1945. There was also a different case, namely the scandal with the short story Dove Hall (Golubnjača), published in 1980 by Jovan Radulović. Although the work, that describes massacres of Serbs in Croatia during the war, was acclaimed and awarded in 1981, its dramatization provoked discussions that resulted in banning its performances.
} 
except for Cyclops, received negative criticism. Although Cyclops was proclaimed an outstanding literary work, immediately upon publication, and is until now believed to be at the core of the Croatian literary canon, there were several critical reviews. The criticism, however, was concerned neither with political content nor subversion with respect to the abandonment of the partisan's myths (emphasizing pacifism, defeatism and passivism). ${ }^{17}$ Such a relatively free writing was possible in Yugoslavia not because the Yugoslav state was liberal but because such literature was not considered by the key political figures, in both lower and higher positions, as dangerous to Yugoslav unity.

We are now in a position to re-consider the idea of the collapse of the Yugoslav master narrative in a broader sense. It is true that the national ideas were responsible for dismantling Yugoslav legitimizing mythologies and canonic visions. It is also true that there was a symbolic struggle between national and Yugoslav imageries: between - in Bakhtinian understanding of terms centrifugal and centripetal forces (languages). And it is true that national ideas, to the detriment of the Yugoslav idea, won the struggle. Yet, the struggle between Yugoslav communism and nationalism was the struggle between two collectivistic ideas. I would argue that one should also take into account the struggle between a collective and individual understanding of reality. Artistic creativity, in particular experimental creativity that emphasizes tragic human destiny in war, marked a parallel path for the destruction of the Yugoslav imagery. Since it was embedded with a collectivistic understanding of the world, any individual experience - neglecting or even rejecting the collective obligations of individuals - would always weaken and erode the collective Yugoslav sense of being. Yet, whilst this tendency had influence on the process of Yugoslavia's imagery destruction, it had no essential influence on the building of the new cultural and political agendas, namely the creation of symbolic fundaments of new national states. One can speculate: if it had been more influential, the collapse maybe wouldn't have been so violent. Individualism, no matter how radical it is, always loses in the face of the collectivist demands of war. Maybe for some it would be surprising that two of the authors analyzed in this article, Ranko Marinković and Radomir Smiljanić, politically endorsed national parties in Croatia and Serbia respectively. The failure of individualistic and nuanced approaches to reality in times of conflict, even among figures with a strong sense of individualism in

\footnotetext{
17 For instance Željko Falout in his review published in a prestigious journal Razlog from Zagreb undelines structural and linguistic weaknesses of the novel and its anachronism (Falout, 1970), In an very thorough and well documented review Ante Padišić emphasized that psychology of Melchior and his social contacts with environment are unreliable and not convincing (Padišić, 1970).
} 
writing, opens up a space for more in-depth inquiry. One could take into consideration the role of such intellectuals whose literary work 'speaks' with a different voice than political engagement. 


\section{REFERENCES}

- Banac, I. (1992). The Fearful Asymmetry of War: The Causes and Consequences of Yugoslavia's Demise'. Daedalus, 121, 2, 141-174;

- Czerwiński, M. (2018). Drugi svjetski rat u hrvatskoj i srpskoj prozi, Zagreb: Hrvatska sveučilišna naklada (Biblioteka L).

- Dragović-Soso, J. (2002) Saviours of the Nation. Serbia's Intellectual Opposition and the Revival of Nationalism, London: Hurst \& Company.

- Falout, Ž. (1961). O Zoopolisu i Zoografiji. Razlozi, VI, 5-6, 510-514

- Goulding, D. L. (2002) Liberated Cinema. The Yugoslav Experience 1945-2001, Bloomington: Indiana University Press.

- Jakiša, M. (2009). On Partisans and Partisanship in Yugoslavia’s Art. In M. Jakiša \& N. Gilić (Eds.), Partisans in Yugoslavia. Literature, Film, Visual Arts. (pp. 9-28), Bielefeld, Germany: Transcript.

- Kirn G. (2009). On the Specific (In)existence of the Partisan Film in Yugoslavia's People's Liberation Struggle. In M. Jakiša \& N. Gilić (Eds.), Partisans in Yugoslavia. Literature, Film, Visual Arts. (pp. 197-226), Bielefeld, Germany: Transcript.

- Krleža, M. (1973) Hrvatski bog Mars, Sarajevo.

- Lopušina, M. (1993) Crna knjiga: cenzura u Jugoslaviji 1945-1952, Beograd.

- Marinković, R. (2010) Cyclops, trans. Vlada Stojiljković, ed. by Ellen Elias-Bursać, New Haven: Yale University Press.

- Miller, N. (2007) The Nonconformists. Culture, Politics, and Nationalism in a Serbian Intellectual Circle 1944-1991, Budapest: CEU Press.

- Musabegović, S. (2008) Rat. Konstitucija totalitarnog tijela, Sarajevo: Svjetlost.

- Norris, D. A. (2012). Jovan Radulović's Golubnjača (Dove Hole): Analysis and Context of the Stories and the Play which was Banned in Yugoslavia (1980-1984). The Slavonic and East European Review, 90, pp. 201-228.

- Norris, D. A. (2016) Haunted Serbia. Representations of History and War in the Literary Imagination, Cambridge: Legenda Modern Humanities Research Association and Routledge.

- Padišić, A. (???). Uzaludna prolaznost Melkiora (povodom Marinkovićeva Kiklopa). Mogućnosti, XIII, 9, 984-996.

- Presto, J. (2004). Unbearable Burdens: Aleksandr Blok and the Modernist Resistance to Progeny and Domesticity. Slavic Review, 63, 1, 6-25.

- Raos, M. (1963) Ratnici, Zagreb: Studentski centar Sveučilišta u Zagrebu.

- Richter, A. (2010). Diskurs otpora u kulturnom prostoru krajem 60-ih godina: Slobodan Selenić - Borislav Pekić - Bora Ćosić. In Z. Bojović (Ed.), Naučni sastanak slavista u Vukove dane 39. (pp. 501-509), Beograd, Serbia: Međunarodni slavistički centar.

- Sindbaek, T. (2012) Usable History? Representations of Yugoslavia's difficult past - from 1945-2002, Udgivet: Aarhus University Press.

- Smiljanić, R. (1969) Mirno doba, Beograd: Prosveta.

- Stojanović, D. (1998) Velika avantura filma, Beograd: Institut za film.

- Špoljar, K. (1963/1968) Gvožđe I lovor, Zagreb: Zora. 
- Tadić, Lj. (1975). Order and Freedom. In B. Horvat, M. Markovic, R. Supek (Eds.), SelfGoverning Socialism: A Reader, vol. 1, (pp. 395-415), White Plains, USA: International Arts and Sciences.

- Vervaet, S. (2009). From Memoir to Fiction. Early Yugoslav Partisan Narratives Revised. In M. Jakiša \& N. Gilić (Eds.), Partisans in Yugoslavia. Literature, Film, Visual Arts. (pp. 71-89), Bielefeld, Germany: Transcript.

- Wachtel, A. B. (1998) Making a Nation, Breaking a Nation. Literature and Cultural Politics in Yugoslavia, Palo Alto: Stanford University Press.

- Zimmermann, T. (2012). Introduction. In T. Zimmermann (ed.), Balkan Memories. Media Constructions of National and Transnational Identity, (pp. 11-30), Bielefeld, Germany: Transcript.

- Žunić, D. (1999) Nacionalizam i književnost, Budapest: Open Society Institute. 